\title{
SIKAP IBU TERHADAP PERTANYAAN ANAK TENTANG SEKSUALITAS
}

\author{
Sri Lestari \\ Wisnu Sri Hertinjung \\ Universilas Muhammadiyah Surakarta
}

\begin{abstract}
Mother can give sexual education for their children continuously. Through it children could get attitude and moral values beside information related to. This research aimed of find out mother's attitude toward children questions about sexuality. Forty mothers as research subjects were taken from purposive nonrandom sampling procedure. They are whose having pre-teenage children. Data collected through recorded interviews. Interviews described mother-children communication situation. Research show that mother attitude correspond to children query have 5 variations (1) giving explanation (51,07\%); (2) feeling surprised and confused (17,86\%); (3) asking children to stop asking (2,14\%); (4) postponing answers with assumption that children will find the answers by their own. (12,14\%) and (5) changing conversation topics $(16,43 \%)$. Based on that findings, if is concluded that mothers willingness to give explanation on children question about sexuality indicate their readiness to communicate sexuality topics. Other attitudes indicate mother's un-readiness to respond on childrer's sexuality question.
\end{abstract}

Keywords: mothers attitude, children question, sexuality

\section{Pengantar}

Kemajuan teknologi telah menjadikan internet sebagal media informasi seksualitas yang mudah untuk diakses remaja secara privat. Melalui internet remaja dapat mencari berbagai informasi tanpa batas. Tidaklah mengherankan bila dewasa ini cybersex telah menimbulkan adiksi pada sebagian remaja.

Selain internet, seperti diungkapkan dalam sebuah acara di Trans TV yang mengangkat topik "Fenomena Problematika Seksual pada Remaja" (Kupas Tuntas, 27 Maret 2003, pukul 23.00 WIB), radio, rubrik majalah, koran, dan tabloid juga dijadikan sebagal referensi informasi seksualitas bagi remaja. Mereka mempercayal jawaban yang diperoleh meskipun lawaban tersebut akurasinya rendah dan cenderung menyesatkan. Berinteraksi dengan media massa menjadikan remaja merasa nyaman, tidak malu, dan terjaga kerahasiaannya, karena dapat menyamarkan identitas. Melalui tayangan tersebut diketahui pula bahwa keadaan ini dipicu oleh kegelisahan remaja mengenai masalah seks yang kurang mendapatkan respon, jawaban dan perhatian dari orangtua atat orang dewasa terdekat.

Fenomena di atas sesual dengan sejumlah studi yang menunjukkan bahwa hanya sedikit orangtua yang memberikan pendidikan seksualitas pada anaknya (Masters et.al., 1992; Atwater, 1992; Perkins, etal., 1999). Problem komunikasi ankara 
orangtua dengan anak tentang seksualitas juga terjadi karena adanya perkembangan dan perubahan sosial pada masa yang berbeda, terjadinya gap antar generasi, serta kombinasi antara keinginan orangtua atas status quo dan kehendak anak untuk bertindak independen. Pada masanya orangtua masih kental dengan sikap menabukan seks, dan mereka tidak dlajarkan bagalmana membicarakan masalah seksualltas secara terbuka. Di sisi lain, pada masa kini anak begitu mudah memperoleh informasi seksualitas, baik dengan keinginan sendiri maupun tidak. Bahkan banyak sumber-sumber informasi yang bebas nilal dan cenderung bersifat erotik. Oleh karena itu, komunikasi orangtuaanak ternyata memegang peran penting. Bagi anak, dapat mengkomunikaslkan masalah seksualitas dengan orangtua tidak hanya memberlkanjawaban atas pertanyaan yang diinginkan, tetapi juga memperoleh rasa aman (Phelps, 1993).

Ahli lain, mengungkapkan bahwa orangtua mengalami kesulitan untuk melakukan pendidikan seksualitas dalam keluarga karena merasa pengetahuannya mengenai seksualitas kurang memadai untuk menjawab segala pertanyaan anak. Jika mereka memiliki informasi yang cukup mereka tidak tahu bagaimana menjelaskannya pada anak (Atwater, 1992). Hal Ini menyebabkan berkurangnya sikap keterbukaan dan memunculkan sikap menabukan pembicaraan masalah seks. Saat inl masih ada orangtua dan masyarakat yang menganggap seks adalah persoalan tabu, kotor. dan tidak pantas dibicarakan atau orangtua berdalih belum saatnya untuk membicarakan. Akibatnya, sebagian besar remaja tidak memperoleh kesempatan untuk mengembangkan ketramplian komunikasi yang digunakan untuk mengekspresikan pemikiran, pertanyaan, dan pendapat terhadap seksualitas.

Menurut hasil penelitian Miller selama 20 tahun, komunikasi orangtua dengan remaja tentang topik-topik seksualitas memiliki peran penting untuk dapat memahaml adanya variasi pada sikap dan perilaku seksual remaja (Somers \& Canivez,
2003) seperti sikap teguh untuk tidak melakukan hubungan seksual sebelum menikah. Akan tetapi komunikasi seksualitas orangtua dengan remaja baru akan mempengaruhi sikap remaja bila orangtua dapat mengkomunikasikan topik-topik seksualitas dengan rasa nyaman (Whitaker, et.al., 1999).

Hasil-hasil kajian menunjukkan bahwa orangtua masih diharapkan menjadi sumber informasi dan pelatihan moral bagi pemahaman dan perkembangan seksualitas anak (Algeier \& Allgeier, 1991; Perkins, et.al., 1999). Namun dalam kenyataannya, belum semua orangtua menjalankan perannya sebagal pendidik seksualltas bagi anak-anaknya. Masih ada orangtua yang mengharapkan anak-anaknya mendapatkan pendidikan seksualitas dari sekolah, atau memblarkan anak mencari tahu sendiri dari sumber-sumber yang ada ol luar rumah. Orangtua lebih suka menunggu anak bertanya tentang seksualitas sebagai cara untuk menyampalkan informasi seksualitas daripada bersikap proaktif dengan terlebih dahulu memberitahu anak sebelum anak bertanya (Lestari dan Purwandari, 2002).

Seksualitas merupakan bagian yang mendasar dari kepribadian manusla, dan banyak individu yang menyimpan pertanyaan dan memikirkan toplk ini. Agar kelak tidak terperangkap pada pemahaman yang sempit atau terjerumus pada pengertian yang salah mengenai seksualitas, maka sejak dini anak harus dibantu untuk mengembangkan konsep yang sehat tentang seksualitas manusia (Bruess \& Greenberg, 1981).

Dengan demiklan, sumberterbaik bagl anak untuk mencari tahu jawaban atas rasa ingin tahunya mengenai masalah seksualitas adalah orangtua. Dengan memberikan jawaban pada anak, orangtua dapat menyampaikan informasi yang akurat, komprehensif, sekaligus juga menyampakan sikap dan nilai-nilai moral yang terkandung dalam perilaku seksual. Selain itu, pendidikan seksualitas yang diberikan oleh orangtua lebih terjamin kesinambungannya dibandingkan pendidikan seksualitas yang diperoleh di luar 
rumah. Oleh karena itu seyogyanya orangtua memiliki kesediaan untuk menjawab pertanyaan anak, kapan saja saat anak membutuhkan.

Berpijak dari uraian di atas, penulis ingin mengetahul bagaimana sikap dan isi jawaban yang diberikan oleh orangtua ketika anaknya bertanya tentang seksualitas?

\section{Tinjauan Pustaka}

Ehrenberg \& Ehrenberg (Masters, et.al, 1992) mengemukakan empat pola komunikasi yang digunakan orangtua dalam menyampaikan masalah seksual kepada anakyaitu:

1) Pola sex repressive, orangtua memberi penjelasan kepada anak bahwa seks adalah sesuatu yang kotor, sehingga mereka lebih sering melarang anakanaknya mengucapkan kata-kata yang berhubungan dengan seks.

2) Pola sex avoidant, orangtua bersikap toleran dengan memberikan pengertian secara intelektual bahwa seks itu sehat, tetapl orangtua merasa malu untuk memberi penjelasan kepada anak dan cenderung menghindari diskusi secara langsung tentang seks.

3) Pola sex obsessive, orangtua menganggap seks sebagai sesuatu yang sehat dan benar tetapi sikap mereka terhadap seks sangat bebas, dan cenderung menunjukkan aktivitas yang berkaitan dengan seks secara terbuka, sehingga anak justru merasa tidak nyaman dan tertekan oleh seluruh perhatian yang diberikan tentang seks.

4) Pola sex expressive, orangtua mengintegrasikan seks ke dalam kehidupan keluarga yang seimbang. Orangtua memperkenalkan seks sebagal sesuatu yang sehatdan positif, tetapijuga menekankan kepada anak bahwa tidak ada yang bisa diperoleh secara tergesagesa hanya dengan seks.

Anak akan menjadi sadar akan seksualitasnya, baik orangtua suka atau tidak. Jadi kesadaran diri (self-awareness) akan seksuallitas merupakan suatu hal yang tidak mungkin dihindari. Oleh karena itu, komunikasi seksualitas yang tepat dengan memperhatikan tahap perkembangan kognitif anak memegang peran yang penting.

Plaget (Santrock, 1999) membagi tahap perkembangan kognitif anak menjadi empattahap, yakni: (1) ta hap sensorimotorik, (2) tahap pra-operasional, (3) tahap operasional konkrit, dan (4) tahap operasional formal. Pada tahap sensorimotorik (Iahir 2 tahun) perkembangan mental ditandal oleh pesatnya kemampuan bayi untuk mengorganisasi dan mengkoordinasi sensasi melalui gerakan fisik dan tindakan, yang dinamakan sensorimotorik. Perilaku seksual pada masa ini lebih bersifat eksplorasi diri dan manipulasi diri sebagai bentuk um um dari sex play. Aktivitas bermain dengan genital seringkali terjadi secara kebetulan ketika anak mengeksplorasi bagian tubuh lainnya. Apabila menyentuh bagian genital dirasakan oleh anak sebagai perilaku yang menimbulkan kenikmatan, maka anak akan cenderung mengulangi perilaku terse but (Katchadourian, 1989).

Pada tahap praoperasional (2 tahun 7 tahun) anak mulai membentuk konsepkonsep, penalaran, egosentrisme makin menguat, dan keyakinan-keyakinan yang bersifat animisme. Anak belum mampu membedakan perspektif dirinya dengan perspektif orang lain. Anak juga meyaklni bahwa benda-benda mati seakan-akan hidup dan mampu melakukan tindakan. Perilaku seksual pada masa Ini mulai melibatkan interaksi dengan orang lain, misalnya pada usia 2 tahun anak telah dapat memberikan respon afeksi dalam bentuk sentuhan, pelukan dan ciuman. Perilaku ini dapat disertai dengan unsur erotik atau tidak. Anak usia 2 atau 3 tahun juga telah memilikI rasa ingin tahu tentang dirinya yang ditunjukkan dengan perilaku menyelidikl genital temannya dan menunjukkan genitalnya pada teman lain. Pada usia 5 tahun, anak mulai memiliki pengalaman sociosexual yang dapat diperoleh melalui bermain "rumah-rumahan" atau bermain 'papa-mama' bersama teman-teman sebayanya (Katchadourian, 1989). Melalui permainan tersebut, anak mulai belajar 
tentang peran jenis yang sesuai dengan identitas jenis kelaminnyoyang didasarkan pada pemahaman anak mengenai "dari mana bayi berasal", yakni:

1) Tahap geografis, anak memahami bahwa sebelum dilahirkan tubuh rnanusia ada di suatu tempatyang lain;

2) Tahap ide pembuatan (manufacturing idea), anak meyakini bahwa bayi menjadi ada karena orangtua telah mengkonstruksi bayi sedernikian rupa;

3) Tahap transisi, dimulai ketika anak berusia 7 tahun, anak telah mampu mendasarkan diri pada proses yang lebih natural dari "pernbuatan bayi";

4) Tahap penjelasan fisiologis; penjelasan yang diberikan anak lebih bersifat fisiologis yang mengacu pada sperma dan sel telur.

5) Tahap penjelasan proses, dicapai anak ketika berusia kira-kira 11-12 tahun. Embrio dibayangkan oleh anak sebagai bentuk awal bayi yang sangat kecil yang terdapatdalan sperma atau sel telur.

6) Tahap penjelasan kausalitas, terjadi setelah anak berusia 12 tahun. Pada tahap ini anak telah dapat memberikan penjelasan yang bersifat kausalitas. Mereka dapat memaparkan bersatunya sperma dan sel telur serta kombinasi isi genetikdalan proses konsepsi.

Adapun menurut Sears et. al. (Katchadourian, 1989) ada tiga tipe informasi yang digunakan orangtua untuk mengontrol materi seksual. Pertama, melalui unambiguous labeling, orangtua menunjukkan dan memberikan label terhadap perilaku tertentu sebagai perilaku yang salah tanpa memberikan penjelasan mengapa. Orangtua dapat menyampaikan hal ini pad a anak dalam bentuk perkataan "ítu tidak baik" atau "anak yang baik tidak akan melakukan hal seperti itu". Kedua, melalui nonlabeling, orangtua menghindari isu-isu seksual dengan mengalihkan perhatian anak atau mengganti fokus percakapan dengan materi lain yang kurang sensitif. Misainya ketika anak perempuan bertanya, bagainana ibu bisa hamil. lbu dapat menjawab "ayah dan ibu bercinta" sambil meninggakkan anak, agar pembicaraan tidak meluas dan anak tidak diberi kesempatan untuk bertanya lebih lanjut. Ketiga, melalui mislabeling, aktivitas seksual disalahkan bukan karena perilaku itu sendiri, namun karena alasan yang dibuat-buat. Sebagai contoh, orangtua melarang anak memegang genltainya agar tidak terserang kurnan penyakit

Selain ketiga bentuk kontrol di atas, orangtua dapat pula menghindari pelabelan terhadap seks sama sekali atau mengarahkan tindakan seksual dengan menggunakan istilah-istilah yang ambigu dan membingungkan anak. Kondisi seperti ini ditengaral dapat mencegah anak untuk memahami tentang seks dan membentuk ketidaktahuan anak tentang seks dengan rasa malu dan kecernasan.

\section{Metode Penelitian}

\section{Subyek}

Penelitian ini merupakan penelitian eksptoratif yang mengungkap bagaimana sikap ibu dalam menghadapi pertanyaan seksualitas yang diajukan oleh anak. Teknik yang digunakan dalam pengamblan sampel adalah purposive non random sampling. Subjek dalam penelitian ini adalah para ibu yang memiliki anak praremaja dengan latar belakang pendidikan minimal STA atau sederajat. Jumlah subjek dalam penelitian ini adalah 40 orang, dengan latar belakang pendidikan sebagal berikut:

a) S-1 sebanyak 11 orang;

b) Diploma (D-1, D-2, D-3) sebanyak 12 orang;

c) SLTAsebanyak 17 orang;

Subjek tinggal di pinggiran kota di wilayah eks Karesidenan Surakarta.

\section{Teknik Pengumpulan Data}

Pengambilan data dilakukan dengan wawancara. Wawancara menggunakan alat bantu kaset rekaman yang berisi 7 fragmen sosiodrama yang menggambarkan situasi komunikasi seksualitas di dalam keluarga yang melibatkan orangtua dengan anak. Subjek diminta mendengarkan fragmenfragmen tersebut dan pada setiap akhir fragmen tokoh anak dalarn fragmen tersebut 
mengajukan pertanyaan tentang materi seksualitas yang harus dijawab oleh subjek. Dalam narasi setiap fragmen dijelaskan berapa usia anak yang terlibat dalam situasi komunikasi seksualitas tersebut. Tujuh topik yang ditanyakan oleh anak dan harus dijawab oleh subjek adalah:

1) Darimana bayi berasal (anak yang bertanya berusia 5 tahun);

2) Perkosaan (anak yang bertanya berusia totahun);

3) AIDS (anak yang bertanya berusia 12 tahun);

4) Haid (anak yang bertanya berusia 8 tahun);

5) Payudara (yang baru tumbuh) terasa sakit (anakyang bertanya berusia 10 tahun);

6) Kondom (anak yang bertanya berusia 6 tahun):

7) Mimpi basah (anak yang bertanya berusia 9 tahun);

Setejah mendengarkan satu fragmen, subjek diminta menjawab dan membayangkan seakan-akan anak yang bertanya dalam kaset rokaman adalah putra/putrinya. Bila pertanyaan dalam fragmen sebelumnya telah dijawab, kemudian diperdengarkan fragmen yang berikutnya pada subjek Jawaban subjek direkam dalam kaset dengan menggunakan tape recorder yang berbeda, kemudian jawaban tersebut dibuat verbatim dan dilakukan analisis.

\section{Anallsis Data}

Analisls data dilakukan secara deskriptif untuk mengetahui proporsi variasi sikap ibu dan analisis kualitatif dengan metode analisls is (content analysis) untuk mengkaji slkap yang ditunjukkan ibu dalam menjawab perianyaan anak.

\section{Hasil Penelitian}

Dari analisis isl terhadap jawaban ibu dengan acuan lima pola komunikasi dari Ehrenberg \& Ehrenberg dan tiga tipe Informasi dari Sears et.al. dapat dibuat lima kategorl slkap ibu dalam menjawab pertanyaan seksualitas dari anak, yaitu: a) Memberikan penjelasan pada anak.
Dalam kategori ini ibu memperlihatkan kesediaan memberikan penjelasan pada anak terkait dengan pertanyaan yang diajukan, namun masih kurang dalam penyampaian fakta yang jelas dan lebih menekankan pesan moral (pola sex expressive, informasi unambiguous). Misalnya jawaban Ny. Yani terhadap pertanyaan topik 1 :

.... sebetuinya bapak sama libu litu sudah berusaha bagaimana caranya punya adik, tapi semua itu tergantung sama Allah... yang memberikan. Kalau kita iri selalu berdoa terus sama Allah, nanti lama-lama Allah memberi adjk, nanti perut ibu itu lama-lama bisa membesar. Tapi kalau Allah belum memberi...adik harus sabar menunggu.

Bandingkan misalnya dengan jawaban berikut: "Bayi berasal dari sperma dan ovum yang bertemu di rahim yang berada dalam perut ibu, kemudian Allah menumbuhkannya menjadi janin yang membuat bu hami dan janin akan berada di dalam perut ibu selama sembllan bujan, setelah itu baru lahir menjadi bayi yang lucu".

b) Rasa terkejut yang menyebabkan kegagapan dan kebingungan dalam menjawab.

Dalam kategori ini ibu menunjukkan sikap bingung atau terkejut yang nampak pada responnya secara verbal yang terbatabata dalam menjawab, atau secara langsung mengungkapkan merasa kesulitan untuk menjawab (pola sex avoidant, informasi nonlabeling). Misalnya Jawaban Ny. Zam terhadap pertanyaan toplk 1:

... adik itu ndak bis a dibeli, terus ada prosesnya, dan untuk itu, itu prosesnya ... apa itu, anu membuat adik itu besok kalou anak sud ah besar, sekarang belum tahu ....

Sebenarnya ibu maslh memllikl kesediaan untuk memberl penjelasan yang terlihat dari koreksinya terhadap anak yang menginginkan untuk membeli adik dan berupaya menjelaskan proses yang sebenarnya. Namun ketika 
menyebutkan kata 'proses' dalam benak ibu kemudian terlintas masalah hubungan seksual, yang tidak ia kehendaki untuk menjelaskannya pada anak, maka ibu mengalami kesulitan dan akhirnya tidak jadi menjelaskan.

Di sinilah sering terjadi kesalahan orangtua dalam mempersepsi pertanyaan anak yang belum mencapai tahap berpikir operasional konkrit ( 6 tahun ke bawah). Pada tahap ini anak sebenarnya belum memerlukan penjelasan yang sifatnya proses, hubungan kausalitas, atau penjelasan abstrak. Dengan menjelaskan fakta-fakta yang biasa dilihat oleh anak, misalnya ibu hami dan mengandung bayi, itu seringkali sudah cukup bagi anak.

c) Melarang anak bertanya

Dalam kategori ini ibu secara langsung melarang anak untuk mengajukan pertanyaan mengenai topik tertentu karena topik yang diajukan dianggap kurang pantas untuk dibicarakan, karena anak masih terlalu kecil atau memberikan larangan saja tanpa mengungkapkan alasannya (pola sex repressive). Misalnya jawaban Ny. Emma terhadap pertanyaan topik 6 :

Adikjangan tanya seperti itu dulu ya....

$K a n$ adik belum cukup umur untuk mengetahui hal seperti itu.

Dengan melarang, ego bu akan muncul dengan mengedepankan otoritasnya, sehingga anak akan berhenti bertanya lebih lanjut.

d) Menunda jawaban dengan asumsi anak akan tahu sendiri

Dalam kategori ini ibu tidak bersedia menjawab pertanyaan karena beranggapan bahwa bila anak sudah besar akan dapat memperoleh jawaban pertanyaan yang diajukan dari sumbersumber yang lain (pola sex avoldant, informasi mislabe/ing). Misalnya jawaban Ny. Syarifah terhadap pertanyaan topik 3:

AIDS its penyakitnya orang besar. Penyakit yang tidak baik. Nanti kalau adjk udah besar adik akan tahu sendiri. Kalau sekarang dikasih tahu belumbisa.
Upaya penundaan jawaban yang dilakukan ibu mungkin dikarenakan ibu sudah mempersepsikan anak bertanya tentang masalah yang berkaitan dengan hubungan seks.Atau setidak-tidaknya ibu berusaha menghindari pertanyaan anak lebih lanjut tentang hubungan seks. Akibat dari upaya menunda jawaban ini seringkali membuat ibu menyampaikan fakta yang kurang tepat atau salah. Misalnya 'AIDS ltu penyakitnya orang besar', padahal kenyataannya bayl, anakanak dan remaja juga dapat terpapar penyakit tersebut. Bandingkan misalnya dengan jawaban berikut, "AIDS itu penyakit yang membuat penderitanya kehilangan kekebalan/imunitas tubuhnya, sehingga mudah terkena penyakit lain misalnya flu dan kanker. Bila penderita AIDS sudah terkena penyakit yang lain, maka akan sulit sembuhnya".

e) Mengalihkan topikpembicaraan.

Dalam kategori ini ibu tidak bersedia menjawab pertanyaan anak dan berusaha mengalihkan perhatian anak pada topik pembicaraan lainnya (pola sex avoidant, informasi nonlabeling). Misalnya jawaban Ny. Fathonah terhadap pertanyaan topik 7 :

O ... Mimpi basah itu dik ... mungkin kakakmu itu tadi malam ngimpi mau ke kamar mau pipis. E ... ndak tahunya temyata dia itu pipisnya of atas tempat tidur

Sama halnya dengan upaya melakukan penundaan jawaban, upaya mengalihkan jawaban dilakukan karena bu mengalami kesulitan memformulasikan jawaban yang berkenaan dengan masalah seks. Akibatnya ibu justru memberikan jawaban yang salah dan menyesatkan. Bandingkan misalnya dengan jawaban berikut, "Mimpi basah itu mimpi mengalami kejadian yang menyenangkan, yang menyebabkan keluamya cairan yang disebut semen atau mani dari alat kelamln. Itu merupakan tanda seseorang telah memasuki masa baligh atau remaja dan akan mengalami banyak lagi perubahan fisik dan emosi". 
Secara deskriptif sebaran masing-masing sikap dalam tiap topik tertera dalam tab el 1.

Tabel 1

Sebaran sikap lbu dalam merespon pertanyaan anak

\begin{tabular}{|c|r|r|r|r|r|r|}
\hline No & Menjelaskan & $\begin{array}{l}\text { Bingungl } \\
\text { Terkejut }\end{array}$ & Melarang & Menunda & Mengalihkan & Keterangan \\
\hline 1. & $30 \%(12)$ & $20 \%(8)$ & $0 \%(0)$ & $7,5 \%(3)$ & $45 \%(18)$ & \\
2. & $50 \%(20)$ & $17,5 \%(7)$ & $0 \%(0)$ & $12,5 \%(5)$ & $20 \%(8)$ & \\
3. & $57,5 \%(23)$ & $17,5 \%(7)$ & $0 \%(0)$ & $15 \%(6)$ & $10 \%(4)$ & \\
4. & $77,5 \%(31)$ & $7,5 \%(3)$ & $0 \%(0)$ & $17,5 \%(7)$ & $0 \%(0)$ & \\
5. & $45 \%(18)$ & $25 \%(10)$ & $0 \%(0)$ & $2,5 \%(1)$ & $25 \%(10)$ & Abstain $2,5 \%$ \\
6. & $42,5 \%(17)$ & $25 \%(10)$ & $12,5 \%$ & $15 \%(6)$ & $2,5 \%(1)$ & $(1)$ \\
7. & $55 \%(22)$ & $12,5 \%(5)$ & $2,5 \%(1)$ & $15 \%(6)$ & $12,5 \%(5)$ & \\
\hline Rer & $51,07 \%$ & $17,86 \%$ & $2,14 \%$ & $12,14 \%$ & $16,43 \%$ & \\
ata & $507 \%$ & &
\end{tabular}

\section{Pembahasan}

Dari analisis deskriptif di atas dapat diketahui bahwa secara umum para ibu berusaha menjawab pertanyaan anak tentang seksualitas dengan cara memberi penjelasan $\left(51,07^{\circ}, \%\right)$. Sementara sikap bingung/terkejut, mengalihkan topik pembicaraan dan menunda jawaban memiliki proporsi yang hampir berimbang $(17,86 \%, 16,43 \%$, dan $12,14 \%)$. Sikap melarang merupakan sikap yang paling sedikit $(2,14 \%)$ ditunjukkan oleh ibu. Hal ini dapat diartikan bahwa mengajukan pertanyaan tentang seksualitas pada ibu bukan merupakan hal yang tabu. lbu telah dapat bersikap terbuka dalam menerima pertanyaan seksualitas dari anak. Dengan kata lain, topik pembicaraan tentang seksualitas dapat diterima sebagai bahan diskusi antara ibu dengan anak di dalam keluarga.

Bila ditinjau dari teori pola komunikasi orangtua anak mengenai seksualitas yang diungkapkan Ehrenberg dan Ehrenberg (Masters, dkk, 1992), maka pola yang digunakan oleh para ibu adalah pola sex repressive, sex avoidantdan sex expressive.

Dalam pola sex repressive, ibu melarang anak bertanya tentang masalah seks karena menganggap perilaku tersebut tidak sopan. Adapun dalam pola sex avoidant, ibu sebenamya masih menerima pertanyaan anak, namun merasa malu untuk memberi penjelasan kepada anak atau mengalami kesulitan memformulasikan jawaban yang tepat sehingga cenderung menghindari diskusi secara langsung tentang seks. Pola ini tercermin dalam sikap ibu yang menunda jawaban dengan asumsi anak akan tahu sendiri atau mengalihkan topik pembicaraan. Dengan pola komunikasi sex avoidant, ibu akan cenderung memberikan jawaban yang tidak faktual, salah atau bahkan menyesatkan. Sikap yang diperlihatkan ibu dalam pola sex repressive dan sex avoidant biasanya akan membuat anak berhenti bertanya lebih lanjut. Akibat jangka panjangnya anak dapat memiliki persepsi yang negatif terhadap masalah seksualitas.

Sementara itu, dalam pola sex expressive ibu dapat menerima pertanyaan anak tentang seksualitas sekaligus bersedia memberikan penjelasan. Namun oleh pengaruh budaya yang lebih mengutamakan nilai-nilal kesopanan dan moralitas, ibu masth mengabaikan pemberian informasi yang faktuai dan lebih menekankan pesan moral. Hal ini mungkin juga dikarenakan 
pengetahuan ibu tentang seksualitas sesungguhnya belum cukup memadai untuk mengikuti rasa ingin tahu anak zaman sekarang yang cenderung sangat besar. Padahal saat lbu menunjukkan sikap bersedia memberikan penjelasan, maka akan membuka peluang keingintahuan anak lebih lanjuttentang masalah seksualitas.

Prosentase tertinggi $(77,5 \%)$ untuk sikap menjelaskan nampak pada respon terhadap pertanyaan tentang haid. Para ibu dapat menjelaskan topik ini dengan baik kepada anak, karena memiliki pengalaman tentang haid dan tidak mengalami kesulitan untuk memformulasikan jawaban dalam bahasa yang mudah dipahaml oleh anak. Seperti jawaban yang disampaikan subjek berikut:

"yang namanya haid itu memang mengeluarkan darah dari dalam dik dan itu kalau adik sudah dewasa, sudah SMP itu pasti jug a mengeluarkan darah seperti ibu. Nah kalau mengeluarkan darah itu dikasih ini ... Namanya pembalut ... iं(Topik4, Ny. Jumani, SMA).

Prosentase sikap menjelaskan yang terendah $(30 \%)$ nampak pada topik "darimana bayi berasal", Walaupun ibu memiliki pengalaman hamil dan melahirkan anak, namun ibu mengalaml kesulitan untuk memformulasikan jawaban dalam kalimat yang mudah dipahami oleh anak. Dari respon yang diberikan, nampak pula adanya kekhawatiran bila anak akan menanyakan terjadinya bayi yang dimaknai oleh ibu sebagai akibat dari aktivitas hubungan seksual. Aklbat pemaknaan tersebut, muncul jawaban ibu berikut:

"kalau mau punya adik gilu ya, ...mama dan papa ... apa Ist/lahnya .... Nanti bisa apa itu ... dengan tidur bersama..... dengan istilahnya bersentuhan trus nanti mama dan papa kalau bersatu bisa mempunyai adik" (Topk 1, Dyah S, S-1),

"Kalau ifu harus melalui proses, datangnya adik itu istilahnya, harus melalui prases, yang tahu it hanya seorang ibu dan ayah yang dikat istilahnya perkawinan. Jadi tidak semata seketika itu muncul adik. Jadi harus mempunyai ... harus mempunyai jangka wakt's yang panjang melalui proses" (Topik 1, Ny. Yono,SMA)

Dari jawaban di atas juga dapat dikaji bahwa dalam memberikan Informasi seksualitas pada anak, ibu tidak perlu menyampaikan semua pengetahuan yang dimiliki berkaitan dengan topik yang ditanyakan oleh anak. Idealnya, ibu menyampaikan informasi seksualitas sebatas yang diperlukan anak sesuai dengan tahap perkembangannya. Sebagai contoh. untuk anak balita, jawaban yang bisa disampaikan untuk pertanyaan dari mana bayi berasal adalah dari perut ibu. Untuk anak yang lebih besar dapat berupa "bayi berasal dari pertemuan sel telur dengan sel sperma". Untuk remaja, jawaban yang diberikan berupa "bayl berasal dari pertemuan sel telur dengan sel sperma yang terjadl karena hubungan seksual antara lakilaki dan perempuan". Untuk catatan juga, seringkali orangtua sudah salah mempersepsikan saat mendengar pertanyaan anak tentang seksualitas akan mengarah pada pertanyaan tentang hubungan seks. Padahal dalam tingkat kemampuan berpikir anak, sebenarnya ia memang benar-benar hanya ingin tahu tentang arti dari sebuah istilah.

\section{Kesimpulan}

Dari data-data penelitian ini dapat disimpulkan bahwa pola yang digunakan ibu untuk mengkomunikasikan seksualitas pada anak adalah sex expressive, sex avoldant, dan sex repressive. Sedangkan informasi yang disampaikan lbu masih cenderung unambiguous, non labeling, dan mislabeling. Informasl yang faktual dapat diberikan oleh ibu pada masalah haid, karena intensitas pengalaman ibu terhadap peristiwa tersebut sangat tinggl dan pengetahuannya leb/h baik.

Prosentase terbesar diperlihatkan oleh slkap ibu yang bersedia memberikan penjelasan. Sementara tiga sikap lainnya memiliki prosentase yang hampir sama, yaitu sikap bingung/terkejut dan gagap, 
mengalihkan topik pembicaraan, dan menunda jawaban. Adapun prosentase paling sedikit pada sikap melarang anak untuk bertanya.

Berdasarkan hasil penelitian di atas, dapat disarankan pada para ibu untuk meningkatkan kemampuan dalam mengkomunikasikan materi seksualitas pada anak agar dapat memberikan penjelasan dengan tepat ketika anak bertanya. Akan lebih baik lagi, bila ibu mau berinisiatif dan bersikap proaktif dalam memberikan pendidikan seksualitas pada anak, tanpa menunggu anak bertanya. Upaya peningkatan tersebut dapat dilakukan dengan meningkatkan pengetahuan dan pemahaman terhadap materi seksualitas, mengasah ketrampilan komunikasi melalui pelatihan maupun membiasakan diri untuk mengkomunikasikan materi seksualitas dengan anak.

Keterbatasan dalam penelitian ini antara lain: situasi komunikasi yang disajikan pada ibu berupa rekaman daiam kaset sehingga tidak diketahui bagaimana feedback anak setelah menerima jawaban dari ibu. Bila anak merasa belum puas, tidak dimungkinkan untuk menany akan lebih lanjut pada ibu. Situasi komunikasi yang kurang nyata tersebut juga membatasi ibu untuk terlibat secara aktif dalam mengekspresikan emosi maupun menangkap ekspresi emosi dari anak yang bertanya. Akan lebih baik biia situasi komunikasi dilakukan dalam situasi yang nyata, dalam arti ibu langsung berhadapan dengan anak, agar keterbatasan terse but dapat diminimaikan.

\section{DAFTAR PUSTAKA}

Allgeier, E.R., \& Aligeier, A.R. 1991. Sexual Interactions. Third Edition. Massachusetts: D.C. Heath and Company.

Atwater, E. 1992. Adolescence. Englewood Cliffs, New Jersey: Prentice Hall.

Bruess, C.E., \& Greenberg, J.S. 1981. Sex Education: Theory and Practice. California: Wadsworth Publishing Company.
Katchadourian, H.A. 1989. Fundamenta/s of Human Sexuality. Fifth Edition. Fort Worth: Holt, Rinehart \& Winston inc.

Lestari, S, dan Purwandari, E. 2002. Kemampuan Komunikasi ibu Anak tentang Seksuaiitas Ditinjau dari Tingkat Pengetahuan lbu. Indigenous. Vol. 6, No. 1, Mei, hal 32-39.

Masters, W.H.r Johnson, V.E., \& Kolodny, R.C. 1992. Human Sexality. Fourth Edition. New York: Harper Collins Publishers.

Perkins, E.R., Simnett, l., \& Wright, L. 1999. Evidence-Based Health Promotion. Chichester: John Wiley and Sons.

Phelps, K 1993. Sex Confironting Sexuality. Australia: Harper Collins Pblishers.

Santrock, J.W. 1999. Life Span Development. New York: McGraw Hill.

Somers, C.L., \& Canivez, G.L. 2003. The Sexual Communication Scale: A Measure of Frequency of Sexual Communication Between Parents and Adolescents. Adolescence. Diakses dari www.findarticles.com pada tanggal $\uparrow$ Maret 2008.

Whitaker, D.J., Miller, K.S., May, D.C., \& Levin, M.L. 1999. Teenage Partners' Communication about Sexual Risk and Condom Use: The importance of Parent-Teenager Discussions. Family Planning Perspective. Vol. 31, No. 3 , MaylJune. Diakses dari www.guttmatcher.org pada tanggal 1 Maret2006. 